\title{
CLIMATE CHANGE RELATED POLICY ENVIRONMENT IN AGRICULTURE AND FOOD SECURITY IN NEPAL
}

S. B. Thakur ${ }^{1}$

\begin{abstract}
Agriculture is the main stay of Nepal's economy. This provides about one-third of national GDP and two-third of national employment. Agriculture is highly vulnerable to climate change due to more marginal farmers with small landholding, limited irrigation, low income level, limited institutional capacity, and greater dependency on climate-sensitive natural resources. The adverse effect of climate change on agriculture impacts on farm revenue, employment, income and GDP. Policy formulation in agriculture and food security sector concerning to climate change has become an imperative for poverty reduction, livelihood improvement and economic development. Compliance with global and national agreement, review of existing policy will provide an essential foundation to policy makers, planners and development workers to reform process. This paper intended to find the strength and weaknesses of existing plans, policies, strategies, acts which will support stakeholders in agricultural development.
\end{abstract}

\section{INTRODUCTION}

Agriculture is major economic sector in Nepal, it contributes about one-third of the national gross domestic product (GDP), represents $13 \%$ of total foreign trade and two-third of the employment to economically active population (CBS 2012). About $21 \%$ of the land is cultivated, of which $54 \%$ has irrigation facilities and land holding size is only 0.68 ha per household. Over $50 \%$ of farmers are small holders cultivating land usually less than 0.5 ha. Agriculture in Nepal is mostly rain-fed and which is climate sensitive.

Nepal is the fourth most vulnerable country after Bangladesh, India and Madagascar (Maplecroft, 2012). The countries with the most risk are characterized by high levels of poverty, dense populations, exposure to climate-related events; and their reliance on flood and drought prone agricultural land in Nepal is highly vulnerable to climate change due to its rugged terrain with steep topography, tectonically active geology and related risks of the natural disasters. On contrary, some experiments have shown opposite results, increasing crop yield particularly rice and wheat with increase in climate variables (Malla, 2008). Large proportion of marginal farmers with small landholding, limited irrigation, low income level, limited institutional capacity, and greater dependency of agriculture on climate-sensitive natural resources increase the degree of vulnerability (Regmi and Adhikari, 2007; World Bank, 2008).

In general, a policy is principle, rule, and guideline formulated and adopted to reach long-term goals to influence and determine all major decisions and actions, and all activities take place by the governing institutions. It is a deliberate system of principles to guide decisions and achieve rational outcomes, which is implemented as a procedure or protocol. There are many plans, policies and strategies developed by government of Nepal for agriculture and food security related to climate

Shree Bhagavan Thakur, e-mail: shreebhagavanthakur@gmail.com 
change. The strength and weakness of the plans, policies and strategies need to be studied for longterm planning to address climate change and environment issues.

In this regard, this paper tries to communicate the strength of agriculture and food security related current legal documents, plans, policies, strategies and programmes to insight the policymakers, development workers, climate change advocates and producers for addressing the adverse effects of climate change.

\section{MATERIALS AND METHODS}

This paper is based on review of various national documents of agricultural and livestock sectors. The national legal documents, plans, policies, strategies, programmes and projects related to agriculture and food security were collected from concern ministry, departments, directorates and offices of programme and projects.

Scanning and skimming, and positive sorting was adopted during reviewing. Climate change and environment related important matter were marked and drawn for the study from the Nepal's plans, policies, strategies and programmes. The current plans, policies, strategies, acts, regulations and institutional policy documents were also studied and deliberated briefly.

\section{DISCUSSIONS}

Based on the review of current legal documents, plans, policies, strategies, acts, regulations and institutional documents, the following keen points were drawn which are very much related to climate change in agriculture and food security.

\section{LEGAL PROVISIONS}

\section{NEPAL CONSTITUTION 2072 BS}

Nepal's constitution strongly focused on food sovereignty and Article (36) Right relating to food explained that every citizen shall have the right relating to food, the right to be safe from the state of being in danger of life from the scarcity of food and the right to food sovereignty in accordance with law.

Article 51 (e) Policies relating to agriculture and land reforms stated, inter alia,to make land management and commercialization, industrialization, diversification and modernization of agriculture, by pursuing land use policies to enhance agriculture product and productivity, while protecting and promoting the rights and interests of the farmers, to make proper use of lands, while regulating and managing lands on the basis of productivity, nature of lands and ecological balance; and to provide for the farmers' access to agricultural inputs, agro products at fair price and market.

Under article $51(\mathrm{~h})$, Policies relating to basic needs of the citizens: point (12) provisioned to provide for sustainable production, supplies, storage, security, and easy and effective distribution of foods by encouraging food production in tune with climate and soil, in consonance with the concept of food sovereignty, while enhancing investment in the agriculture sector.

Article (30) Right to clean environment stated in point (1) every citizen shall have the right to live in a clean and healthy environment, (2) the victim shall have the right to obtain compensation, inaccordance with law, for any injury caused from environmental pollution or degradation, and (3) 
The Article shall not be deemed to prevent the making of necessarylegal provisions for a proper balance between the environment and development, in development works of the nation.

\section{Sustainable Development Goals (SDG), 2016-30}

Nepal has agreed to the commitment of the United Nations Sustainable Development Goal (SDG) in UN Summit on September 25, 2015. Among 17 Goals, goal two focused on "End hunger, achieve food security and improved nutrition and promote sustainable agriculture". And Goal thirteenth on "Take urgent action to combat Climate change and its impact".

\section{National Development Plan}

Goal of the thirteenth plan was up scaling of Nepal from least developed country to the level of developed country by 2022, and climate change is considered one of the challenges to overcome barriers to reaching to the goal. Including natural resource and environment conservation, agriculture was one of the important priorities among 7 priorities of the plan. There was mandatory of implementing climate change adaptive development initiatives keeping current and future negative impact of climate change in mind.

\section{Priority of 14th Plan (approach paper)}

The Fourteenth Plan stated that in spite of increasing the production and productivity of agriculture for supply of increasing population food and other basic needs, Nepal is importing agriculture commodity every year. It clearly stated that agriculture system has likely to failed completely due to youth migration for employment, poor supply of agriculture inputs, loss of soil fertility, high cost of production, competition with import products, stratified agriculture land and change in land utilization, variation in weather because of climate change, So, it is urgent need to result oriented actions with effective agricultural plans for future commercial agriculture.

Fourteenth Plan specified as challenge of transformation of subsistence agriculture in competitive and commercial for industrial development and climate change adaptation action to reduce energy crisis and possible disaster for socio-economic development efforts. Since large number of small and medium farmers in agriculture, it has challenge to build adaptive capacity to climate change and various natural disasters. This plan has taken strategy to develop and disseminate climate smart agriculture technology for reducing the negative effect of climate change and disaster.

\section{Strategies and visions}

\section{AGRICULTURE DEVELOPMENT STRATEGY (ADS) 2015}

ADS has vision of agricultural sector growth through four strategic components including governance, productivity, profitable commercialization, and competitiveness. The acceleration of inclusive, sustainable, multi-sector, and connectivity-based growth is expected to result in increased food and nutrition security, poverty reduction, agricultural trade competitiveness, higher and more equitable income of rural households, and strengthened farmers' rights. All outcomes, outputs, and activities of the ADS will contribute to improve food and nutrition security either directly or indirectly.

Among four components, Component two of the ADS focused on productivity for food and nutrition security by (i) increasing the volume of food production in Nepal in a sustainable way through higher productivity and sustainable use of natural resources; and (ii) reducing vulnerability of farmers 
through improved food/feed/seed reserves, improved preparedness and response to emergencies, and climate smart agricultural practices.

ADS's Climate Change and Natural Resource Management:

Available evidence on climate change in Nepal indicates increasing temperatures and different patterns of monsoon precipitations. The impact of climate change on agriculture in Nepal is currently studied, but even the preliminary evidence suggests the need of introducing appropriate adaptation mechanisms to increase resilience of farmers to climate change. At the same time it is important to understand the feasibility of mitigation mechanisms including clean development mechanisms and disaster risk reduction that could be beneficial to farmers. The issue is how to ensure sustainable modernization of agriculture and commercialization while strengthening resilience to climate change.

Improved productivity of land and labor is at the cornerstone of the ADS. Agricultural productivity requires the adoption of appropriate technologies and know-how to increase efficiency and sustainability of agricultural production consistently with market demand and food security needs of subsistent farmers. Among four measures to raise agricultural productivity efficient and sustainable practices and use of natural resources (land, water, soils, and forests); and increased resilience to climate change and disasters are climate change related.

Though, the Millennium Development Goals (MDG) Progress Report 2010 stated that the decreased poverty rate and reduction in the population suffering chronic food insecurity. The report also focused that greater attention to environmental conservation and adaptation to climate change.

\section{SEED VISION 2013-25}

The Seed Vision aims to increase crop productivity, raise income and generate employment opportunities through self-sufficiency, import substitution and export promotion of quality seeds. Seed visioning assignment was implemented for the many reasons, inadequate location specific varietal choices and limited number of crop varieties mostly due to climate change is a major one.

Among four major significant direct and indirect impacts the two impacts i.e. ensuring food security and reducing poverty, and contributing in biodiversity conservation and adapting to adverse impact of climate change which is related to climate change.

\section{Biodiversity conservation and climate change}

The chapter includes the context of changing climate scenario in Nepal, it also focused particularly in developing and promoting climate resilient crop varieties (drought, flood and heat tolerant, etc.) using rich biodiversity. The promotion of climate resilient seed varieties will sensitize farming communities on climate change and allows for climate adaptation options in terms of food production. This will have impact on stabilizing food production and reducing risks of farming communities, resulting in increased livelihood options and strengthened capacity to adapt adverse effect of climate change.

NARC strategic vision 2011-30

The vision of the Nepal Agricultural Research Council (NARC) is to tap institutional, human, and financial resources from the government and a wider spectrum of stakeholders-civil society, research centers, donors, and ultimately the private sector-to move the system from agricultural research and development to agricultural research for development. 
NARC has given future research priorities will be based on creating and scaling up technologies for environmental sustainability including food security, poverty reduction, value addition, export promotion and cost effectiveness.

\section{NARC's Natural Resource Management and Climate Change Thematic Area}

Environment problems such as deforestation, nutrient mining, soil erosion and land degradation, eutrophication of surface water, increased encroachment of marginal lands for cropping, degradation of range and pasture lands and reduced level of agro-biodiversity are directly related to increased pressure on land and water. There is need to maintain long-term balance between sustainable agriculture, natural resources, and ecological security which is possible through continuous research and development in the sectors. In spite of all those, NARC also needs to further refine its policy on conservation of agro-biodiversity and agricultural genetic resources through in-situ and ex-situ conservation strategies.

It also focused on agro-ecological diversity and environmental sustainability, due consideration has given in creating and adjusting the technologies (Indigenous knowledge, traditional practices and local resources) to exploit benefits arising and counter any negative effect brought out by climate change.

\section{POLICIES}

\section{NATIONAL AGRO-BIODIVERSITY POLICY 2007 (2063 BS)}

This policy vision is to conserve and sustainable use of agricultural genetic resources / materials and associated traditional knowledge with the participation of concerned stakeholders for present and future generations. In national and international level, effort has been made to conserve biological diversity. The policy intends to recognize agro-biodiversity as an integral component of biodiversity based on the spirit of international treaties/ agreements and national initiatives in order to ensure social, economic and environmental benefits to the Nepalese people.

The objectives focused, inter alia, to enhance agricultural growth and ensure food security by conserving, promoting and sustainably using agro-biodiversity; to create effective management, commercialization and use of agricultural genetic resources in the present context of exploiting local national and international markets and in international regulations on trade; to contribute in maintaining sustainable ecological balances(ecosystems services) over time, and to promote the conservation and use of agro-biodiversity in the contexts of national seed, food quality and safety, and product marketing regulations.

\section{NATIONAL AGRICULTURE POLICY, 2004 (2061)}

The objective of this policy is to create an enabling environment for agriculture-led rural development. It emphasizes competitiveness of agriculture sector encouraging farmers to go for commercial production. The policy aims at increasing productivity and promoting natural resources to utilize them in the interest of farmers. The long-term vision of the agriculture sector is to bring improvement in the living standards through sustainable agricultural development by transforming subsistence agricultural system into a commercial and competitive agricultural system. The policy emphasizes on increased agricultural production and productivity, making agriculture competitive in regional and world markets with commercial agriculture system, and conserving, promoting and utilizing natural resources, environment and bio-diversity. 
NATIONAL SEED POLICY, 2000 (2056 B.S.)

The main aim of formulating this policy is to effectively manage production, processing and testing of high quality seeds and their timely availability to the farmers. The Seed Act of 2045 B.S. and Seed Regulation, 2054 B.S. signifies contribution of the quality seeds in agricultural production. The objectives ensure the availability of quality seeds of different crops in a required quantity, production of quality seeds and promotion of export, and conservation of genetic characteristics of the indigenous seeds and maintain patent right. The main feature of the policy which is directly and indirectly related to climate change; it has focused on conservation of agro-biodiversity and establishment of breeders rights over new variety of seeds. It proposed for conducting 'research' (which may also be construed as risk assessment) on GMO seeds.

\section{NATIONAL FERTILIZER POLICY, 2002 (2058 B.S.)}

This policy was formulated to support agricultural production by ensuring supply (production, import and distribution) of good quality fertilizer. This Fertilizer Policy is sub-component of the Government's broad National Agriculture Policy as set out in the Agriculture Perspective Plan (19952015). The aim of this policy is to enhance agricultural productivity through improvement in soil fertility and thereby contribute to the national goal of poverty alleviation. Specifically, this policy emphasizes on the provision of conditions (policy and infrastructure management) for enhancing fertilizer consumption; and promotion of integrated plant nutrients management system for efficient and balanced use of fertilizer. The policy adopts the strategy which relates climate change for sustainable use of manures among other strategies to achieve its objectives i.e. to manage Integrated Plant Nutrients System.

The use of chemical fertilizers causes GHG emission. The policy need to focus on alternate of chemical fertilizers with discouraging strategies.

\section{IRRIGATION POLICY, 2014 (2070 B.S.)}

There are many climate related risks associated with the irrigation infrastructure and their utilization. The water resources management and variability of water supply is the major issue related to the irrigation sector. Drought conditions reduce the effectiveness of irrigation systems and can cause long term damage to infrastructure and losses in crop production. Similarly, flooding causes direct destruction of infrastructure and sedimentation within irrigation systems. The vision of this policy is to avail the sustainable and reliable year round irrigation facilities to all the agricultural lands so as to contribute to agricultural productivity. Extension of irrigation services is important in the context of meeting the objectives of increasing agricultural production and reduction of poverty.

This demands promotion of conjunctive use of ground and surface water based irrigation systems along with new/non-conventional irrigation systems such as rain water harvest, pond irrigation; sprinkler irrigation, drip irrigation and treadle pump irrigation. In the country, the irrigation systems developed so far are limited to run-off the river system. To make the system good for round the irrigation, it is necessary to develop storage so that the problem of low flow of rivers during the winter season can be mitigated to some extent. The policy emphasizes implementing reservoirbased and inter-basin water transfer types of water sector strategy development and integrated water resources management. The policy aims to develop irrigation facility for the achievement of the objectives related to the climate change, to avail round the year irrigation facility through effective management of existing water resources; develop institutional capacity of water users for sustainable management of existing systems; and enhance knowledge, skills and institutional 
working capability of technical human resources, water users and NGOs relating to development of irrigation sector.

\section{RANGELAND POLICY, 2012(2068)}

In high hill and mid-hills region, livestock farming is the main source of livelihood of people and rangeland is the major basis for livestock production. Rangeland management is expected to contribute to livelihood improvement and food security of the people, reduce internal migration and minimize the effects of climate change. For providing clear direction for managing uncontrolled extraction or harvesting of rangeland resources like herbs and NTFPs, preventing the declining rangeland productivity and biodiversity due to uncontrolled grazing, minimizing the effects of climate change and environmental degradation, evaluating their roles in carbon sequestration, and promoting indigenous knowledge, skills, technologies, this policy was formulated and implemented, inter alia, recognizes the Department of Livestock Services as the lead agency for rangeland management, considers rangelands as under constant and serious threats, which require urgent attention, envisages sustainable use and development of natural rangeland with a view to support livelihood of the local people and also about the development of livestock sector through sustained feed supply and grazing management.

\section{NATIONAL LAND USE POLICY, 2012 (2069 B.S.)}

This policy was formulated considering the growing concerns about increasing fragmentation of fertile land and unplanned urbanization. The policy, inter alia: to ensure optimum use of land and control land fragmentation; help establish a link between agricultural with industrial sectors, and encourage optimal use of land for agriculture; categorize for the first time in the country, land into seven categories - agricultural, forest, residential, commercial, public, industrial, and others; to make sure that fertile land is used for farming only, and bar dealings in land allocated for agriculture; and establish the Land Use Management Department, which will have experts from agriculture, irrigation, environment, urban development and management sector.

\section{LAND USE POLICY, 2015}

This policy was formulation to manage the settlements safely from the natural disaster, after the devastating earth quake in April 2015. This realized the problems, inter alia, adverse condition of food security due to reduction of agriculture production and productivity because of increased use of fertile land in unproductive purposes, most of land under fallow and uncontrolled fragmentation. Soil erosion, floods landslides and desertification due environmental pollution and climate change causing to loss of natural resources like environmental degradation and loss of bio-diversity and forests. Ensure food security increasing agricultural production and productivity through conservation and best utilization of agricultural land, and reducing climate change impacts, natural disaster, biodiversity and environmental conservation are major challenge. These things are strongly considered in objectives, sectoral policies and strategies of the policy.

\section{AGRICULTURAL MECHANIZATION PROMOTION POLICY, 2014}

Labor shortage has become a challenging issue in recent years for agriculture development due to migration of young farmers from the rural areas of Nepal. Thousands of youths have out-migrated for finding employment (in the urban centers and abroad). To address this challenging issue and 
modernize agriculture, agricultural mechanization policy has been formulated. Agricultural mechanization involves use of different types of power: human, animal, mechanical and electrical. It helps to achieve timeliness in field operations, increased productivity and reduced cost of production, and minimized farm drudgery. It also imparts dignity to farm work and makes farming attractive to educated rural youth. The policy's salient features includes, inter alia, increasing competitiveness, modernizing and commercializing Nepalese agriculture through appropriate mechanization, and focusing on environment, women and youth farmer-friendly agricultural mechanization.

\section{BIOTECHNOLOGY POLICY, 2006 (2063B.S.)}

In order to address the existing challenges of a developing country like ours, this policy formulated to obtain the potentials opened up by biotechnology. The implementation of this policy may assist in increasing the production of food grains through biotechnology, developing a new technology of medical treatment, controlling environmental pollution and promoting various industrial sectors.

The vision of this policy is to increase production and productivity by means of research and development of biotechnology as well as transfer of technology, and improve the living standard of Nepali people by achieving a significant progress in the field of public health and environment.

The overall objective of this policy is to make contribution to the reduction of poverty by developing and expanding biotechnology with its use in the sectors of comparative benefit and its application as a basis of key substitute for the development of the country as well as environment protection and public welfare. The salient features includes, inter alia, fulfill a minimal need of food grains and nutritious food for growing population, thereby assisting in the reduction of poverty, and encourage research and development of biotechnology contributing for developing the forests, agriculture and food sectors in an internationally competitive and environmentally sustainable manner.

\section{CLIMATE CHANGE POLICY, 2011 (2067 B.S.)}

Nepal formulated targets-based Climate Change Policy in 2011 to address climate change impacts, and help develop people's coping capacities. The main goal of this policy is to improve the livelihood by mitigating the adverse impacts of climate change, adapting to it, adopting low carbon emission socio-economic development path and promoting the support and cooperation as per the commitments at the national and international mechanism related to climate change. Main features of the policy, inter alia, consider the importance of the sectors that are vulnerable to climate change; enhance the climate adaptation and resilience capacity of local communities for optimum utilization of natural resources and their efficient management; adopt the low carbon development path by making socio-economic development climate change friendly and resilient; allocate at least 80 percent of the total budget directly at program implementation level/areas; establish a semiautonomous climate change center to coordinate the programs and projects; develop the capacity for identifying the present and future impacts of climate change, quantifying the impacts, adopting adaptation measures to be safe from the risks and adverse impacts of climate change; and establish a separate Climate Change Fund for implementing programs related to climate adaptation and 
resilience, and low-carbon development, identifying risks, carrying out studies and research and developing and utilizing technologies.

\section{PLANS AND PROGRAMMES}

\section{PLANS}

\section{AGRICULTURE PERSPECTIVE PLAN (APP)}

Government of Nepal has been implementing a 20-year Agriculture Perspective Plan (APP) since 1997 with a view to commercialize agriculture, develop overall economy and alleviate poverty. This plan has identified priority inputs and outputs for consolidated investment in order to commercialize agriculture sector. High value horticultural commodities and agriculture business are priority outputs of APP. It has also proposed to establish strong forward and backward linkages of agricultural production. As focused by the APP, commercialization of agriculture and thereby increasing production and income of farmers is the main strategy of Three Year Plan (2011-2013).

APP design gave priority to certain key inputs (i.e. irrigation, fertilizer, technology, roads and power, and financial credit for agriculture), and key outputs (i.e. livestock, high value crops, agribusiness, and forestry), that were envisaged to deliver the policy's expected social, economic and environmental impacts. These priorities remain relevant to in the present context, in addition to current and emerging issues though the period of the plan was completed. The ADS 2015 has been developed following the National Agriculture Policy 2004.

\section{Zero Hunger Challenge National action Plan (2016 - 2025)}

The country adopted ZHC initiative as a national agenda holding the vision for preparing a National Action Plan to eradicate hunger by 2025 . To move ahead with this process, a roadmap was prepared by MoAD to launch the ZHC initiative and then formulate the National Action Plan covering a period of ten years starting from 2016 till 2025. The objective is to ensure "rights to food" by improving food and nutrition security of people to achieve a society free of hunger and malnutrition by 2025 . In this regard, it emphasizes on fostering right based access to food and its proper utilization. Its specific objectives are, inter alia, strengthen sustainable production process for accelerated growth of the agriculture sector; improve food and nutritional status of all people in the country; and improve social protection system for the poor suffering from hunger, poverty and malnutrition.

\section{NATIONAL BIODIVERSITY STRATEGY AND ACTION PLAN 2014-2020}

The description and analysis of past efforts and achievements, and formulation of strategies and actions are focused around six thematic areas: (a) Protected Areas, (b) Forests outside Protected Areas, (c) Rangelands, (d)Wetlands, (e) Agriculture, and (f)Mountains.

In Nepal, biodiversity is closely linked to the livelihoods and economic well-being of most people. The subject touches upon almost every aspects of Nepalese life, including agricultural productivity, food security, climate, water resources and aesthetic value for society. Agro-biodiversity is the backbone for sustainable development of agriculture, food security and poverty alleviation as it provides both the immediate needs and long-term sustenance of the country's farming communities. 
Diversity of crops and animals is particularly vital to the country's marginalized communities for maintaining their food security.

\section{PROGRAMMES}

Programmes and projects will be real image of the policies and plans of any sectors. A national flagship program (FANUSEP) that includes subprograms on Nepal Agricultural and Food Security Project (NAFSP), Food and Nutrition Security Plan of Action (FNSP), and a new comprehensive program on food and nutrition security that will be developed and started over the course of the first 5-year period of the ADS.

Nepal has implemented Pilot Program on Climate Resilience (PPCR) has been implemented among 9 countries in year 2009 with support of climate investment fund, World Bank and Asian development bank. Building Resilience to Climate-related hazards project is one among 5 projects which was initiated by Government of Nepal in coordination with Ministry of Population and Environment (MoPE).

\section{CONCLUSION}

Nepal's main economic sector, agriculture is adversely impacting due to climate change. Climate change has negative impacts on crop and livestock production and productivity, pest and disease infestation, land degradation, soil fertility, animal fertility and behavior, quality and quantity of food, feeds and fodder, biodiversity, gene pool and others. The adverse effect in food security and livelihoods at national, household and individual level affects farm revenue, employment, income and finally on GDP. Study of existing state of the policy documents are required to capitalize to policy maker, researchers, academia and development workers on existing provision for addressing climate change and environmental issues in the agriculture and food security. The studied plans, policies and guidelines have played an important role in order to adapt and minimize the impacts of climate change regarding agriculture and food security in Nepal. It has helped to reduce the hunger, increase sustainable products, end poverty, malnutrition, control land fragmentation and building resilience against climate change hazards, support research in terms of agriculture, food production and forestry.

Nepal Constitution 2072, Sustainable Development Goals, Agriculture Development Strategy, National Agriculture Policy, Climate Change Policy, Agriculture Prospective Plan, Zero hunger challenge and National Action Plan has helped directly for the formation of climate change related policies for agriculture and food security whereas, National Seed Policy, National Agro-biodiversity Policy, Irrigation Policy, Rangeland policy, National Land use Policy, Biotechnology Policy, Agricultural Mechanization Promotion Policy has indirectly helped in the formation of climate change policies related to agriculture and food security. Policies and plans formulated before climate change policy 2011, has very less consideration of climate change and environment aspects and the policies and plans after 2011, have gradually included and addressed climate change aspects in form of mitigation or adaptation. 
There is adequate space in existing policy, plans and strategies for integrating the medium and long term adaptation measures to reduce vulnerability to the impacts of climate change in agriculture and food security.

\section{ACKNOWLEDGEMENT}

We would like to express our sincere thanks to the Ministry of Population and Environment (MOPE), and UK Aid, Act on Climate Today, Oxford Policy Management and Practical Action for providing the opportunity in NAP formulation process for this study. We also thank to Ministry of Agricultural Development (MOAD), Ministry of Livestock Development (MoLD) and NAP team for their sincere help and cooperation.

\section{REFERENCES}

CBS, 2012.Nepal Living Standard Survey, 2011/12.Government of Nepal Central Bureau of Statistics. Kathmandu, Nepal

Malla, G. 2008. "Climate Change and Impact on Nepalese Agriculture", Journal of Agriculture and Environment, Review Paper, Volume 9, June.

Maplecroft (Global Risk Analysis). 2011. -Climate change risk atlas 2011. Accessed June 12. http://maplecroft.com/search/climate+change+vulnerability+ranking.

MoAC, 1997.Agriculture Perspective Plan(APP), 1997. Ministry of Agriculture and cooperatives, HMG, Nepal.

MoAC, 2000. National Seed Policy, 2000. Ministry of Agriculture and cooperatives, HMG, Nepal.

MoAC, 2002. National Fertilizer Policy. 2002. Ministry of Agriculture and cooperatives, HMG, Nepal.

MoAC, 2007.National Agro-biodiversity Policy.2007.Ministry of Agriculture and cooperatives, Government of Nepal.

MoAD, 2014.A report on Agriculture Development Strategy (ADS) 2015-2030, Ministry of Agricultural Development, GoN, Singhdurbar.

MoAD, 2014.Agricultural Mechanization Promotion Policy, 2014.Ministry of Agricultural Development, GoN, Singhdurbar.

MoE, 2010. National Adaptation Program of Action (NAPA) report. Ministry of Environment, Singhdurbar, GoN

MoEST, 2006.Biotechnology Policy. 2006. Available at http://www.mope.gov.np

MoEST, 2011.Climate Change Policy. 2011, Ministry of Science Technology and Environment /Department of Hydrology and Meteorology

MoFSC, 2014. National Biodiversity Strategy and Action Plan .2014-2020.Ministry of Forest and Soil Conservation, Singhdurbar, GoN.

Molr, 2014.Irrigation Policy, 2014.Ministry of Irrigation, Singhdurbar, GoN.

MoLRM, 2012. National Land use Policy. 2012. Ministry of Land Reform and Management, Singhdurbar, GoN

MoLRM, 2015, Land Use Policy 2015. Ministry of Land Reform and Management, Singhdurbar, GoN

NARC, 2011.NARC Strategic Vision. 2011-2030. Nepal Agriculture Research Council, Khumaltar Kathmandu

NARC. 2012. NARC vision. Nepal Agriculture Research Council, Khumaltar Kathmandu

Nepal Constitution.2015, Government of Nepal.Available at Nepal Law commission.http: / /www.lawcommission.gov.np/

NPC, 2016. Fourteenth Plan (FY 2016/17 - 2019/20) - Approach Paper, Kathmandu: National Planning Commission, Government of Nepal.

Regmi, B. R. and Adhikari, A., 2007. Human Development Report 2007/2008 - Fighting Climate Change: Human Solidarity in A Divided World - Country Case Study-Nepal, Human Development Report Office, Occasional Paper No 57

SDG. 2015. UNDP. UN summit 2015 September.Sustainable Development Goals (SDG).2015-2030.

Zero Hunger Challenge National Action Plan (2016 - 2025).National Action Plan. Government of Nepal. 